\title{
In situ U-Pb dating of xenotime by laser ablation (LA)-ICP-MS
}

\author{
LIU ZhiChao ${ }^{1,2}$, WU FuYuan ${ }^{1 *}$, GUO ChunLi ${ }^{3}$, ZHAO ZiFu $^{4}$, YANG JinHui ${ }^{1} \&$ SUN JinFeng ${ }^{1,2}$ \\ ${ }^{1}$ State Key Laboratory of Lithospheric Evolution, Institute of Geology and Geophysics, Chinese Academy of Sciences, Beijing 100029, China; \\ ${ }^{2}$ Graduate University of Chinese Academy of Sciences, Beijing 100049, China; \\ ${ }^{3}$ Institute of Mineral Deposits, Chinese Academy of Geological Sciences, Beijing 100037, China; \\ ${ }^{4}$ School of Earth and Space Sciences, University of Science and Technology of China, Hefei 230026, China
}

Received May 5, 2011; accepted July 1, 2011

\begin{abstract}
Xenotime is an ideal mineral for U-Th-Pb isotopic dating because of its relatively high $\mathrm{U}$ and Th contents, but typically low concentration of common $\mathrm{Pb}$. These characteristics, and the fact that it is widespread throughout various types of rocks, suggest that the U-Th-Pb dating of xenotime has broad applications. Studies of U-Pb dating on xenotime by ion microprobe (such as SHRIMP) have increased in recent years, whereas studies by laser ablation (LA)-ICP-MS are still rare. In this study, we developed a technique for U-Pb dating of xenotime using the $193 \mathrm{~nm}$ ArF laser-ablation system and Agilent 7500a Q-ICP-MS. To evaluate the reliability of our method, a xenotime standard, BS-1, was analyzed and calibrated against another xenotime standard, MG- 1 . The weighted mean ${ }^{206} \mathrm{~Pb} /{ }^{238} \mathrm{U}$ ages of $510.1 \pm 5.2 \mathrm{Ma}(2 \sigma, n=21), 509.8 \pm 4.3 \mathrm{Ma}(2 \sigma, n=21)$ and $510.0 \pm 4.6 \mathrm{Ma}(2 \sigma, n=21)$ were obtained using beam diameters of 16, 24 and $32 \mu \mathrm{m}$, respectively. These ages are identical to those determined by ID-TIMS method (weighted mean ${ }^{206} \mathrm{~Pb} /{ }^{238} \mathrm{U}$ age of $508.8 \pm 1.4 \mathrm{Ma}$ ), which supports the reliability of our LA-ICP-MS method. We also analyzed xenotimes in leucogranites from South Tibet and granites from Xihuashan in southern China, and obtained accurate and precise ages. Nevertheless, we observed systematic differences in $\mathrm{Pb} / \mathrm{U}$ fractionation among xenotime, monazite and zircon. The matrix-effect resulted in either under-correction or over-correction of fractionation, and thus led to inaccurate ages. Thus, a matrix-matched material is required for U-Pb dating of xenotime by LA-ICP-MS.
\end{abstract}

xenotime, laser ablation (LA)-ICP-MS, U-Pb dating

Citation: $\quad$ Liu Z C, Wu F Y, Guo C L, et al. In situ U-Pb dating of xenotime by laser ablation (LA)-ICP-MS. Chinese Sci Bull, 2011, 56: 2948-2956, doi: 10.1007/ s11434-011-4657-y

In the last two decades, in situ dating analyses of accessory minerals have been developed rapidly and widely applied to decipher the formation and evolution of the Earth and other geological processes. These in situ techniques may reveal the complex growth history of minerals, and also avoid the tedious chemical work that is currently required by the traditional isotope dilution thermal ionization mass spectrometry (ID-TIMS) method. However, in situ U-Pb dating techniques mostly are applied to zircon samples. For rocks without zircons, it is difficult to evaluate their ages of formation and evolution. At this point, the development of geochronological methods for other accessory minerals is urgently required. For example, numerous studies have been

*Corresponding author (email: wufuyuan@mail.iggcas.ac.cn) conducted on baddeleyites from mafic-ultramafic rocks and perovskites from kimberlites (such as [1-4]). Nevertheless, it is difficult to determine the deposition age of siliciclastic sedimentary rock because of the lack of appropriate minerals for isotopic dating. Fortunately, U-Pb dating method of xenotime recently has been developed using SHRIMP, which provides an excellent approach to determine the age of siliciclastic sedimentary rock [5-9]. As a result, U-Pb dating of xenotime has received extensive attention and its applications have expanded rapidly.

Xenotime $\left[\mathrm{YPO}_{4}\right]$ is a common accessory mineral in a variety of rocks, such as pelitic metamorphic rocks, peraluminous granites and siliciclastic sedimentary rocks. This mineral is enriched in rare earth elements (REE), and is an ideal candidate for $\mathrm{U}-\mathrm{Pb}$ dating because of its high content 
of $\mathrm{U}$ and negligible content of common $\mathrm{Pb}$. Currently, in situ dating of xenotime is commonly conducted by ion microprobe [5-20], which can yield precise and accurate ages. However, the expense of this instrumentation hinders the wide application of this technique. Chemical dating by electron microprobe (EMPA) is another important approach for xenotime dating [21-25]. However, the low precision of this technique limits its applications in geological processes. The recently developed LA-ICP-MS technique provides an alternative approach to accurately date with low costs, but this technique is commonly used for zircon and rarely for xenotime U-Pb dating [26-28]. In this study, we developed a technique for in situ U-Pb dating of xenotime by LA-ICPMS and applied it to xenotimes in granites from both South Tibet and South China.

\section{Instrumentation}

All measurements were carried out at the MC-ICP-MS laboratory in the Institute of Geology and Geophysics, Chinese Academy of Sciences. The laser ablation system consists of an ArF excimer laser generator with wavelength of $193 \mathrm{~nm}$ and a laser optical system with a laser beam homogenizing system, both of which are manufactured by Coherent Company. The laser spot size can be adjusted to 5, $10,16,24,32,44,60,90,120$ and $160 \mu \mathrm{m}$, and the frequency can be adjusted from 1 to $20 \mathrm{~Hz}$. The highest energy density is $45 \mathrm{~J} / \mathrm{cm}^{2}$. An Agilent 7500a Q-ICP-MS was utilized in this study and the detailed description of this instrument was given in a previous study [29].

\section{Analytical methods}

The analytical method for $\mathrm{U}-\mathrm{Pb}$ dating of xenotime in this study is similar to that for zircon. Clear and visibly inclusion-free grains of xenotime were handpicked under a binocular microscope $(\times 40)$ and fixed onto a piece of glass with double-sided tape, over which a PVC ring was placed. A mixture of epoxy and hardener was placed into the PVC ring. Upon thorough solidification, the PVC ring was peeled off from the glass and the mount was polished until the surface became even and the sample was revealed. Transmission, reflection and back-scattered electron images were taken and used to examine samples for inclusions, cracks and zonation. Before analyses, the mounts were ultra-sonicated in ethanol to eliminate possible contamination.

The instrumental setting was similar to that described in Xie et al. [29]. Prior to routine analysis, a tuning solution was used to optimize the ICP-MS, and then the P/A factor of the detector was corrected. During laser ablation, helium was utilized as the carrier gas, which was mixed with argon gas prior to entering the ICP torch. The parameters of these two gases were optimized through continuous ablation of
NIST SRM 610 reference material glass to obtain maximum and stable signal intensity and to suppress oxide formation by minimizing the $\mathrm{UO}^{+} / \mathrm{U}^{ \pm}\left(\mathrm{UO}^{+} / \mathrm{U}^{ \pm}<0.5 \%\right)$ ratio. The ICPMS measurement was carried out utilizing time-resolved analysis and peak hopping at one point per mass. The dwell time was $0.015 \mathrm{~s}$ for ${ }^{204} \mathrm{~Pb},{ }^{206} \mathrm{~Pb},{ }^{208} \mathrm{~Pb}, 0.030 \mathrm{~s}$ for ${ }^{207} \mathrm{~Pb}$, and $0.010 \mathrm{~s}$ for ${ }^{232} \mathrm{Th}$ and ${ }^{238} \mathrm{U}$. The energy density used throughout the measurements was either 10 or $12 \mathrm{~J} / \mathrm{cm}^{2}$. Spot size and laser pulse frequency were adjusted according to the concentrations of $U$ and Th. The parameters of laser ablation and Q-ICPMS are shown in Table 1.

$\mathrm{U}-\mathrm{Pb}$ fractionation and instrumental mass discrimination were corrected using external standards. Data were collected in discrete runs, comprising eight unknown analyses bracketed before and after by two analyses of external standard. Each spot analysis was obtained from approximately $20 \mathrm{~s}$ of background acquisition and $65 \mathrm{~s}$ of data acquisition. Data reduction was carried out with the software package GLITTER 4.0 (GEMOC, Macquarie University). All the measured isotope ratios of the standard throughout the sample analyses were regressed and corrected using the reference values. Standard deviations of calibrated isotope ratios take into account deviations from the sample, standard, and reference values. The relative standard deviations of reference values were set at $2 \%$. None of the xenotimes required common $\mathrm{Pb}$ correction. The $\mathrm{U}-\mathrm{Pb}$ concordia ages and weighted mean ages were calculated with the ISOPLOT/ EX 3.23 software package.

\section{Experimental calibration}

\subsection{Standards}

Xenotime standards MG-1 and BS-1 are derived from metamorphic rocks, Minas Gerais, Brazil. MG-1 is a doubly

Table 1 Parameters of LA-ICP-MS

\begin{tabular}{lclr}
\hline \multicolumn{4}{c}{ ICP-MS parameters } \\
\hline RF power & $1260 \mathrm{~W}$ & Einzel 2 & $1 \mathrm{~V}$ \\
Carrier gas & $1.23 \mathrm{~L} / \mathrm{min}$ & Omega Bias & $-100 \mathrm{~V}$ \\
Makeup gas & $0.0 \mathrm{~L} / \mathrm{min}$ & Omega (+) & $0.2 \mathrm{~V}$ \\
Extract 1 & $-189.1 \mathrm{~V}$ & Omega (-) & $-1.3 \mathrm{~V}$ \\
Extract 2 & $-62 \mathrm{~V}$ & QP Focus & $2.6 \mathrm{~V}$ \\
Einzel 1,3 & $-130 \mathrm{~V}$ & Plate Bias & $-8.7 \mathrm{~V}$ \\
& $0.015 \mathrm{~s} \mathrm{for}{ }^{204} \mathrm{~Pb},{ }^{206} \mathrm{~Pb},{ }^{208} \mathrm{~Pb}, 0.030 \mathrm{~s}$ & for ${ }^{207} \mathrm{~Pb}$, and \\
Dwell time & $0.010 \mathrm{~s} \mathrm{for}{ }^{232} \mathrm{Th}$ and ${ }^{238} \mathrm{U}$ & \\
\hline \multicolumn{5}{c}{$\mathrm{Laser} \mathrm{system} \mathrm{parameters}$} \\
\hline Wavelength & $193 \mathrm{~nm}$ & & \\
Energy density & $10 \mathrm{~J} / \mathrm{cm}^{2}, 12 \mathrm{~J} / \mathrm{cm}^{2}$ & \\
Spot size & 16,24 and $32 \mu \mathrm{m}$ for xenotime and monazite, \\
Pulse rate & $44 \mu \mathrm{m}$ for zircon \\
Carrier gas (helium) & $3 \mathrm{~Hz}$ for xenotime and monazite, $6 \mathrm{~Hz}$ for zircon \\
Background & $0.55 \mathrm{~L} / \mathrm{min}$ \\
Sample data acquisition & $65 \mathrm{~s}$
\end{tabular}


terminated euhedral crystal of about $2.2 \mathrm{~cm} \times 1.3 \mathrm{~cm} \times$ $1.3 \mathrm{~cm}$ in size [9]. Excellent concordant ages have been determined by both TIMS and SHRIMP methods. This standard is judged to be $490 \mathrm{Ma}$ based on the ${ }^{206} \mathrm{~Pb} /{ }^{238} \mathrm{U}$ age of $490.1 \pm 1.1 \mathrm{Ma},{ }^{207} \mathrm{~Pb} /{ }^{235} \mathrm{U}$ age of $490.4 \pm 1.0 \mathrm{Ma}$ and ${ }^{207} \mathrm{~Pb} /{ }^{206} \mathrm{~Pb}$ age of $491.7 \pm 2.0 \mathrm{Ma}(2 \mathrm{SD}, n=6)$, utilizing TIMS analyses [9]. BS-1 is an euhedral crystal of about $1.7 \mathrm{~cm} \times 0.8 \mathrm{~cm} \times 0.8 \mathrm{~cm}$ in size. TIMS analyses gave consistent ages with ${ }^{206} \mathrm{~Pb} /{ }^{238} \mathrm{U}$ being of $508.8 \pm 1.4 \mathrm{Ma}$, ${ }^{207} \mathrm{~Pb} /{ }^{235} \mathrm{U}$ of $508.2 \pm 1.2 \mathrm{Ma}$ and ${ }^{207} \mathrm{~Pb} /{ }^{206} \mathrm{~Pb}$ of $505.2 \pm 2.4$ $\mathrm{Ma}(2 \mathrm{SD}, n=5)$ [9]. To evaluate the precision and accuracy of the U-Pb dating method developed here, we operated different laser ablation conditions. By using a laser energy density of $10 \mathrm{~J} / \mathrm{cm}^{2}$, a repetition rate of $3 \mathrm{~Hz}$ and MG-1 as the external standard, the obtained weighted mean ${ }^{206} \mathrm{~Pb} /{ }^{238} \mathrm{U}$ ages for BS-1 under spot sizes of 16, 24 and 32 $\mu \mathrm{m}$ were $510.1 \pm 5.2,509.8 \pm 4.3$ and $510.0 \pm 4.6 \mathrm{Ma}(2 \sigma, n$ $=21$ ), respectively (Figure 1 ). All these ages are concordant and identical to the reference value yielded from ID-TIMS, indicating the reliability of our method in both precision and accuracy (U-Pb data are listed in Appendix 1).

\subsection{Matrix-effect}

To evaluate the influence of matrix-effect during laser ablation, both zircon and monazite were used as external standards to correct instrument bias and isotopic fractionation. The same laser conditions were applied to monazite standard 44069 and xenotime BS-1 (i.e. with a energy density of $10 \mathrm{~J} / \mathrm{cm}^{2}$, a repetition rate of $3 \mathrm{~Hz}$, and spot sizes of 16,24 and $32 \mu \mathrm{m}$ ), but a different condition was operated for zircon standard 91500 because of its lower concentration of $U$ (i.e., energy density of $10 \mathrm{~J} / \mathrm{cm}^{2}$, a repetition rate of $6 \mathrm{~Hz}$, and spot size of $44 \mu \mathrm{m}$ ).

The results are listed in Appendix 1 and plotted in Figure 1. When calibrated against zircon standard 91500, the obtained ages of BS-1 are slightly discordant and much younger than the reference age by ID-TIMS (ca. $490 \mathrm{Ma}$ ). The weighted
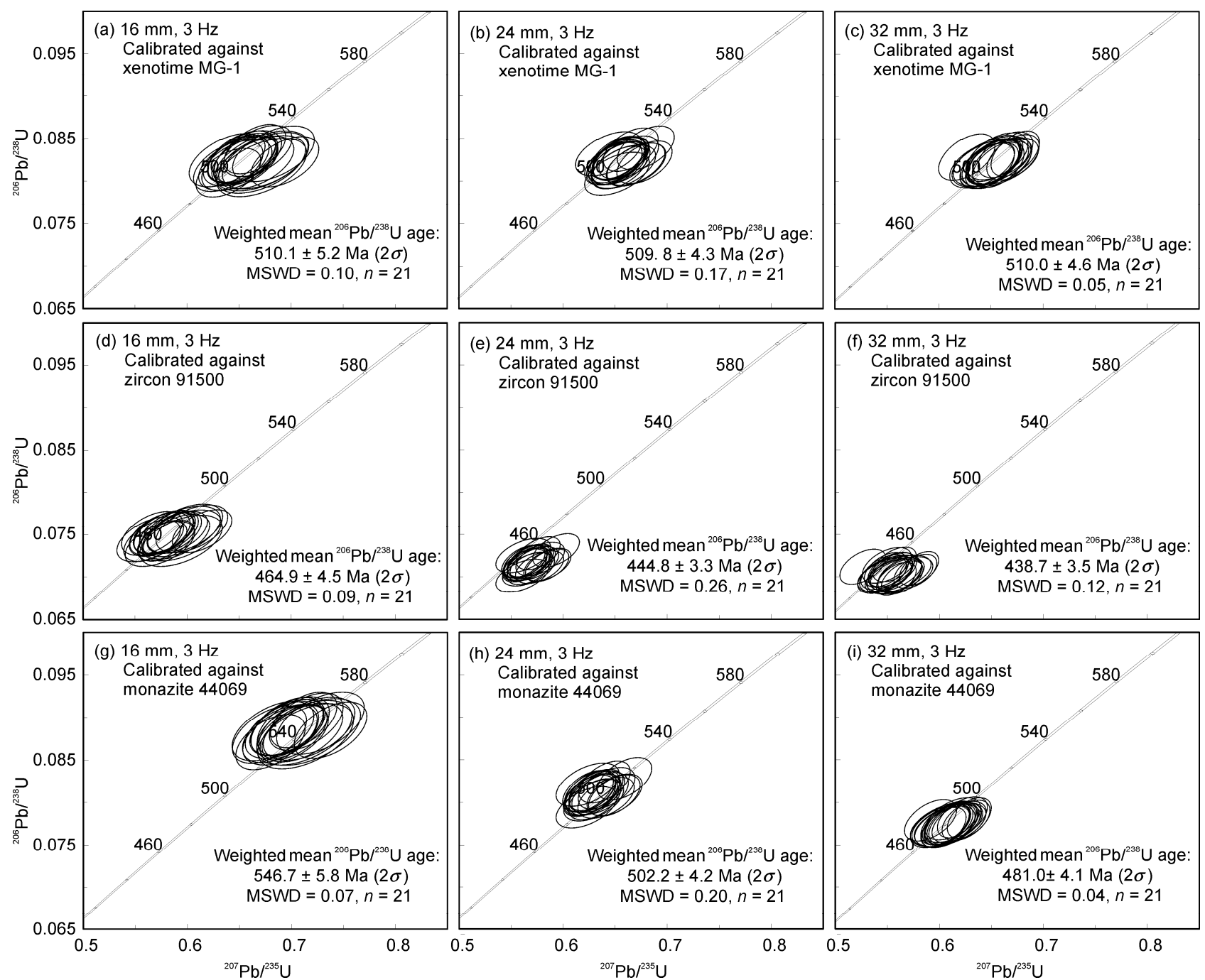

Figure $1 \mathrm{U}-\mathrm{Pb}$ dating of xenotime BS-1. 
mean ${ }^{206} \mathrm{~Pb} /{ }^{238} \mathrm{U}$ ages of $464.9 \pm 4.5 \mathrm{Ma}, 444.8 \pm 3.3 \mathrm{Ma}$ and $438.7 \pm 3.5 \mathrm{Ma}(2 \sigma, n=21)$ were obtained under spot sizes of 16,24 and $32 \mu \mathrm{m}$, respectively. These obtained results indicated a younging trend with increasing spot size. When calibrated against monazite standard 44069, concordant but inaccurate ages were obtained for BS-1. The weighted mean ${ }^{206} \mathrm{~Pb} /{ }^{238} \mathrm{U}$ ages of $546.7 \pm 5.8,502.2 \pm 4.2$ and $481.0 \pm 4.1$ Ma $(2 \sigma, n=21)$ were obtained using spot sizes of 16,24 and $32 \mu \mathrm{m}$, respectively. We found a similar relationship between age and spot size when zircon was used as a standard.

The weighted mean ${ }^{206} \mathrm{~Pb} /{ }^{238} \mathrm{U}$ ages for xenotime BS-1 obtained under different conditions are summarized in Table 2 . These results suggest that it is possible to successfully correct instrument bias and isotopic fractionation during laser ablation under different operating conditions, if a matrix-match standard is used. Thus, we applied xenotime standards MG-1 or BS-1 as external standards in the following studies.

\section{Applications}

\subsection{Kudy leucogranite in South Tibet}

After the Indo-Eurasia collision, a distinctive magmatism of leucogranites was developed in Himalaya during the Miocene, as shown by two subparallel E-W belts in South Tibet-the North Himalayan Gneiss Dome to the north, and the High Himalayan Granitic belt to the south. Formation of these leucogranites is related to continental crustal anatexis and intra-continental tectonic processes. Thus, the Himalayan leucogranites provide an opportunity to study the dynamics of continental collision. However, research on Himalayan leucogranites is not sufficient, especially for their emplacement ages, largely because of the lack of magmatic zircons in these rocks. In most cases, zircons in these leucogranites are commonly inherited from the source rocks and mantled by thin magmatic growths $(<20 \mu \mathrm{m})$. Therefore, these zircons represent a significant challenge for both conventional isotopic dilution and in situ dating techniques. Moreover, because of their high concentration of U, magmatic zircons generally yield older ages by SIMS dating [30]. Fortunately, monazite and xenotime are common in these leucogranites, allowing an approach to precisely determine the crystallization age of these granites.

Dominated by two-mica granite, the Kudy leucogranite is located on the northeastern Sajia dome, and intruded into

Table 2 The obtained weighted mean ${ }^{206} \mathrm{~Pb} /{ }^{238} \mathrm{U}$ ages of xenotime BS-1

\begin{tabular}{cccc}
\hline $\begin{array}{c}\text { Spot size } \\
(\mu \mathrm{m})\end{array}$ & $\begin{array}{c}\text { Calibrate against } \\
\text { xenotime MG-1 }(\mathrm{Ma})\end{array}$ & $\begin{array}{c}\text { Calibrate against } \\
\text { zircon } 91500(\mathrm{Ma})\end{array}$ & $\begin{array}{c}\text { Calibrate against } \\
\text { monazite } 44069(\mathrm{Ma})\end{array}$ \\
\hline 16 & $510.1 \pm 5.2$ & $464.9 \pm 4.5$ & $546.7 \pm 5.8$ \\
24 & $509.8 \pm 4.3$ & $444.8 \pm 3.3$ & $502.2 \pm 4.2$ \\
32 & $510.0 \pm 4.6$ & $438.7 \pm 3.5$ & $481.0 \pm 4.1$ \\
\hline
\end{tabular}

early gneisses. A medium to fine-grained garnet-two-mica granite sample 09FW126 was collected from the middle part of the pluton to for our laboratory study. Xenotimes from this sample are colorless to light yellow, rich in tiny inclusions and often associated with zircons. No significant zonation was observed in backscattered electron images. Twenty-three $\mathrm{U}-\mathrm{Pb}$ analyses under spot size of $24 \mu \mathrm{m}$ yielded a weighted mean ${ }^{206} \mathrm{~Pb} /{ }^{238} \mathrm{U}$ age of $28.1 \pm 0.2 \mathrm{Ma}$ $(2 \sigma, n=23)$ (Figure 2, Appendix 2). This age is consistent with previously reported ID-TIMS ages of zircon and xenotime $(27.5 \pm 0.5 \mathrm{Ma})[31]$.

\subsection{Xihuashan granite in southern China}

Xihuashan is the world-famous large vein-type tungsten deposit in South China. Discovered in the early 1930s, this deposit was developed in the endo- and exocontact zones of the Xihuashan granite, which was thought to be a multiintrusive granitic pluton $[32,33]$. Based on textural variations, the Xihuashan granite can be subdivided into 5 stages, i.e. porphyritic medium-grained biotite monzonitic granite (G-1), medium-grained biotite monzonitic-alkali feldspar granite (G-2), medium to fine-grained biotite monzonitic granite (G-3), porphyritic fine-grained monzonitic granite (G-4) and aplite (G-5) [34]. However, the emplacement and mineralization ages of Xihuashan remain unclear, largely because of large errors and low precisions given by previous analyses of $\mathrm{Rb}-\mathrm{Sr}$ whole rock isochron or mica $\mathrm{K}-\mathrm{Ar}$ methods. The emplacement age of the granite has been reported in a range of 138 to $159 \mathrm{Ma}$ (http://www. nimrf.net.cn/). The reported mineralization ages range from 137 to $139 \mathrm{Ma}$ [35], which is consistent with the age of the G-3 granite but $20 \mathrm{Ma}$ younger than that of the G-1 granite. Using the LA-ICP-MS technique, Yang et al. [36] reported zircon $\mathrm{U}-\mathrm{Pb}$ ages of $158.7 \pm 2.5,155.0 \pm 2.0-156.5 \pm 2.1$ and $158.0 \pm 1.9$ Ma for G-1, G-3, G-5 granites, respectively. These ages are identical within analytical errors, implying that the different stages of granites were emplaced simultaneously

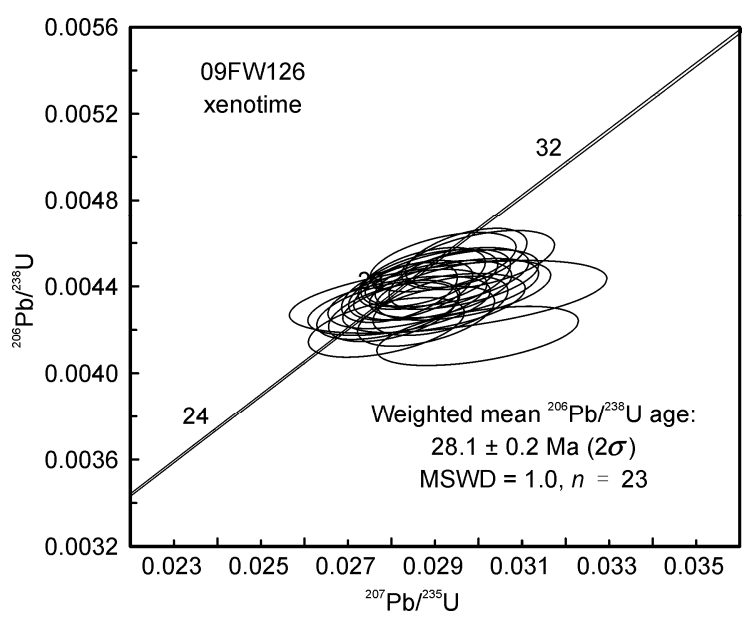

Figure $2 \mathrm{U}-\mathrm{Pb}$ ages of xenotime from Kudy leucogranite. 
within a short period. Recently, Wang et al. ${ }^{1)}$ reported Re-Os isochron ages varying from $155.6 \pm 1.4 \mathrm{Ma}$ to 160.7 $\pm 4.0 \mathrm{Ma}$ for molybdenites associated with the tungsten-ore, which are identical to the age of the G-1 granite, within errors.

Xenotime is observed throughout the Xihuasan complex. Wang et al. [37] suggested that xenotime crystallized at the magmatic stage and experienced further evolution at the late-magmatic and hydrothermal stage. Xenotimes from G-1, G-2, G-3 and G-5 granites were separated for U-Pb dating in this study. The xenotime grains are mostly euhedral, with a diameter of $\sim 50-100 \mu \mathrm{m}$, with some containing inclusions. Under back-scattered electron images, xenotimes from G-2 and G-3 granites show no zonation, whereas xenotimes from G-1 and G-5 usually contain traces of thorite. The obtained $\mathrm{U}-\mathrm{Pb}$ ages are almost concordant (Figure 3 ). The weighted mean ${ }^{206} \mathrm{~Pb} /{ }^{238} \mathrm{U}$ ages are $153.1 \pm 1.1 \mathrm{Ma}(\mathrm{G}-1$, $2 \sigma, n=22), 153.2 \pm 1.3 \mathrm{Ma}(\mathrm{G}-2,2 \sigma, n=24), 153.1 \pm 1.2$ $\mathrm{Ma}(\mathrm{G}-4,2 \sigma, n=24)$ and $152.9 \pm 1.3 \mathrm{Ma}(\mathrm{G}-5,2 \sigma, n=20)$, respectively (Appendix 3 ). These ages are marginally identical to those Re-Os ages of molybdenites, within errors.
Therefore, we suggest that the Xihuashan granite was emplaced in a relatively short period of time and the ores were formed simultaneously with the granites, and that repeated igneous activity over a long time period is unlikely. However, the age difference between xenotime and zircon needs further investigation.

\section{Discussion}

\subsection{Advantages and disadvantages of xenotime U-Pb dating}

Xenotime is an ideal mineral for U-Pb dating because of the following properties: (1) High $\mathrm{U}$ and negligible common $\mathrm{Pb}$ contents (Figure 4). The reported data suggest that diagenetic xenotimes typically contain $\sim 1000 \mathrm{ppm} \mathrm{U}$, and most of the xenotimes that crystallized from pegmatites contain $>$ $10000 \mathrm{ppm} \mathrm{U}$. In addition, xenotime is one of the few U-bearing accessory minerals with low concentrations of common $\mathrm{Pb}$. Although U-bearing accessory minerals are common in variety rocks, the ones with low common $\mathrm{Pb}$
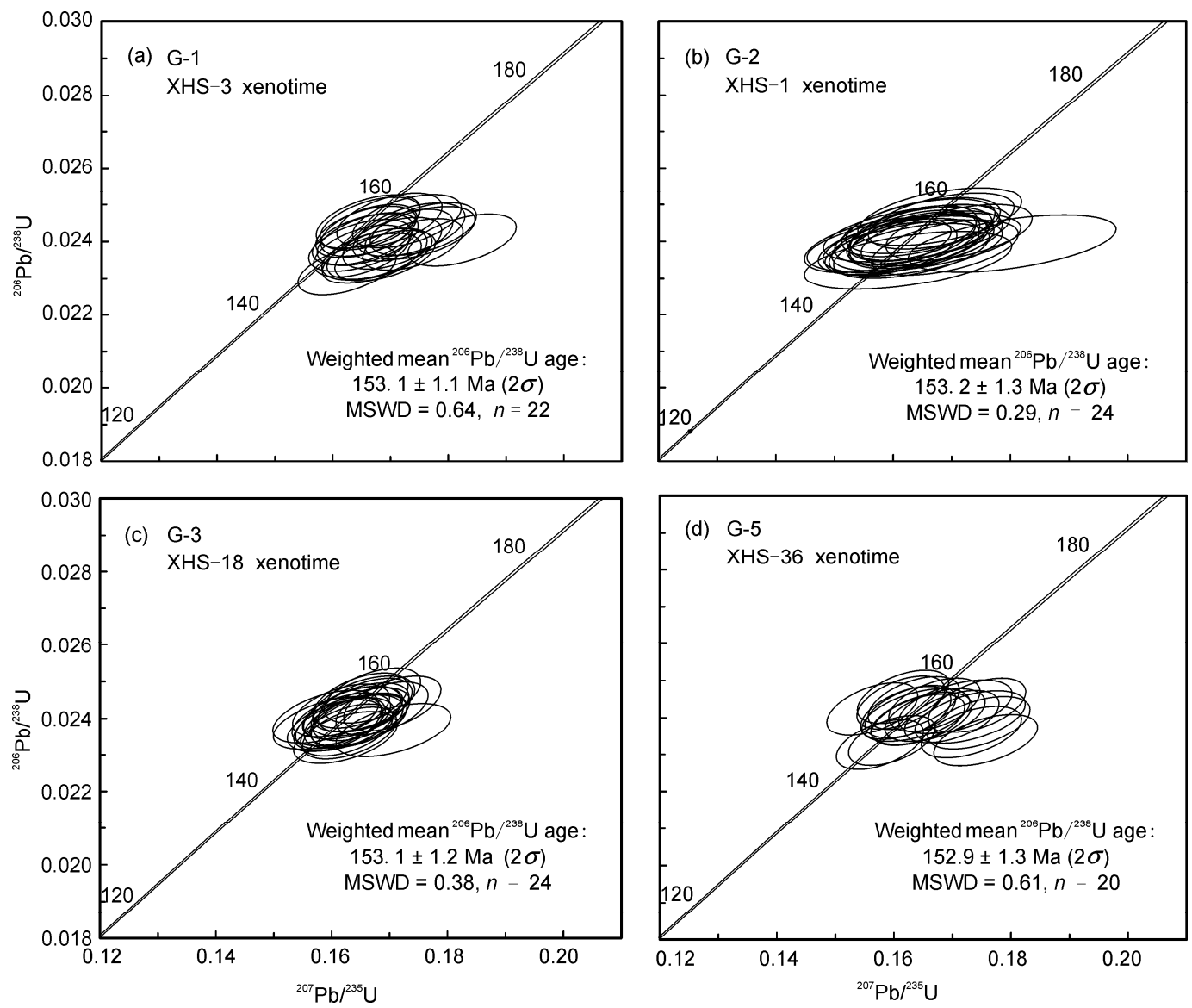

Figure $3 \mathrm{U}-\mathrm{Pb}$ ages of xenotime from the Xihuashan granite.

1) Wang F Y, Ling M X, Liu Y L, et al. The chronology of Tungsten mineralization of Xihuashan: Constraints for Mesozoic tectonic evolution, South China. 2009 National Symposium on Petrology and Geodynamics, 364 

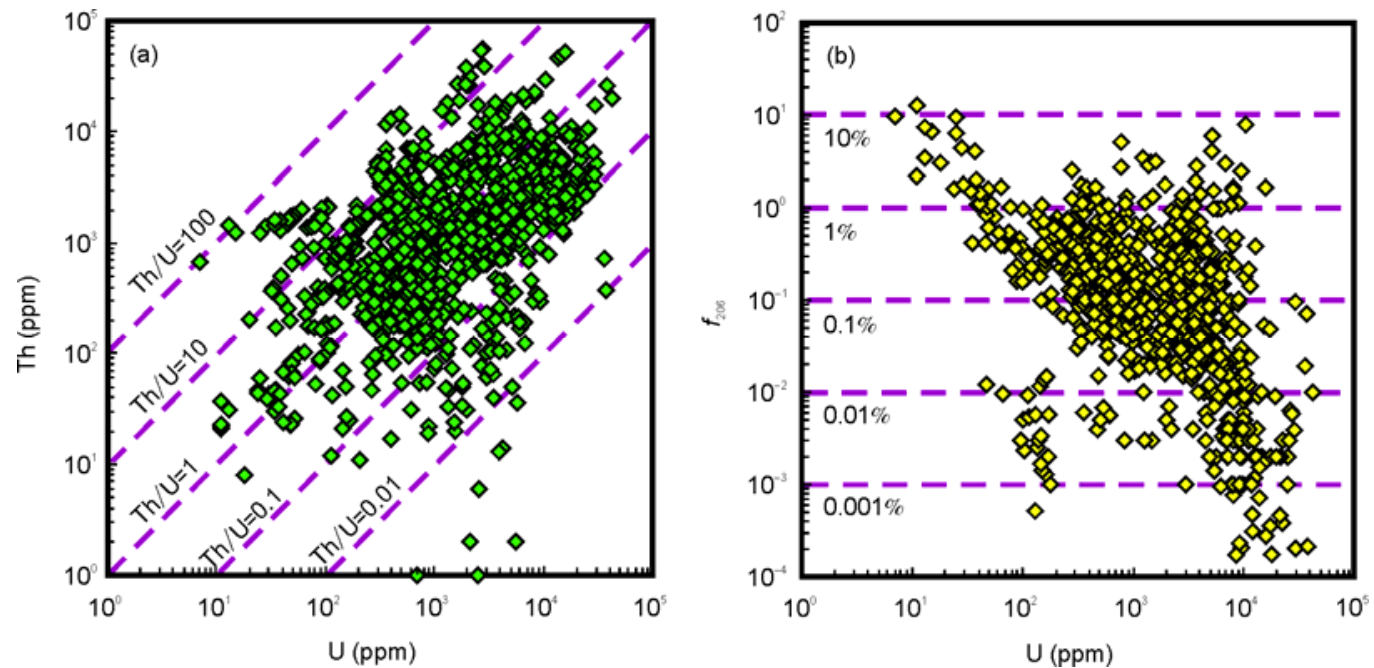

Figure 4 Concentrations of U-Th and common $\mathrm{Pb}$ for xenotime [5-21,31,38,42,45-48].

contents include only zircon, baddeleyite, zirconolite, calzirtite, monazite and xenotime. (2) High Th content can yield accurate $\mathrm{Th}-\mathrm{Pb}$ age. Thus, three independent ages can be obtained from a single xenotime grain, making it a highly rigorous dating tool. Although monazite has been also widely used for $\mathrm{U}-\mathrm{Th}-\mathrm{Pb}$ geochronology, it often yields reverse discordant ages as a result of incorporation of unsupported ${ }^{206} \mathrm{~Pb}$ due to ${ }^{230} \mathrm{Th}$ disequilibrium. In comparison, xenotime generally gives concordant ages because of its much lower Th/U ratio compared to monazite (such as [38]). (3) High closure temperature for $\mathrm{Pb}$ and highly resistant to diffusive $\mathrm{Pb}$ loss. Following the methods of Dodson [39], the calculated $\mathrm{Pb}$ closure temperatures of xenotime at different cooling rates are shown in Figure 5 [40,41]. Closure temperature of $\mathrm{Pb}$ diffusion in xenotime is close to or even higher than that in zircon, and much higher than other common U-bearing accessory minerals, such as calzirtite, titanite and apatite. (4) The widespread occurrence in various rock types makes xenotime a very useful mineral to date many geological processes, such as hydrothermal alteration, metamorphism and diagenesis. Furthermore, xenotime is also used for $\mathrm{Sm} / \mathrm{Nd}$ and $\mathrm{Lu} / \mathrm{Hf}$ isotopic dating [42,43]. In
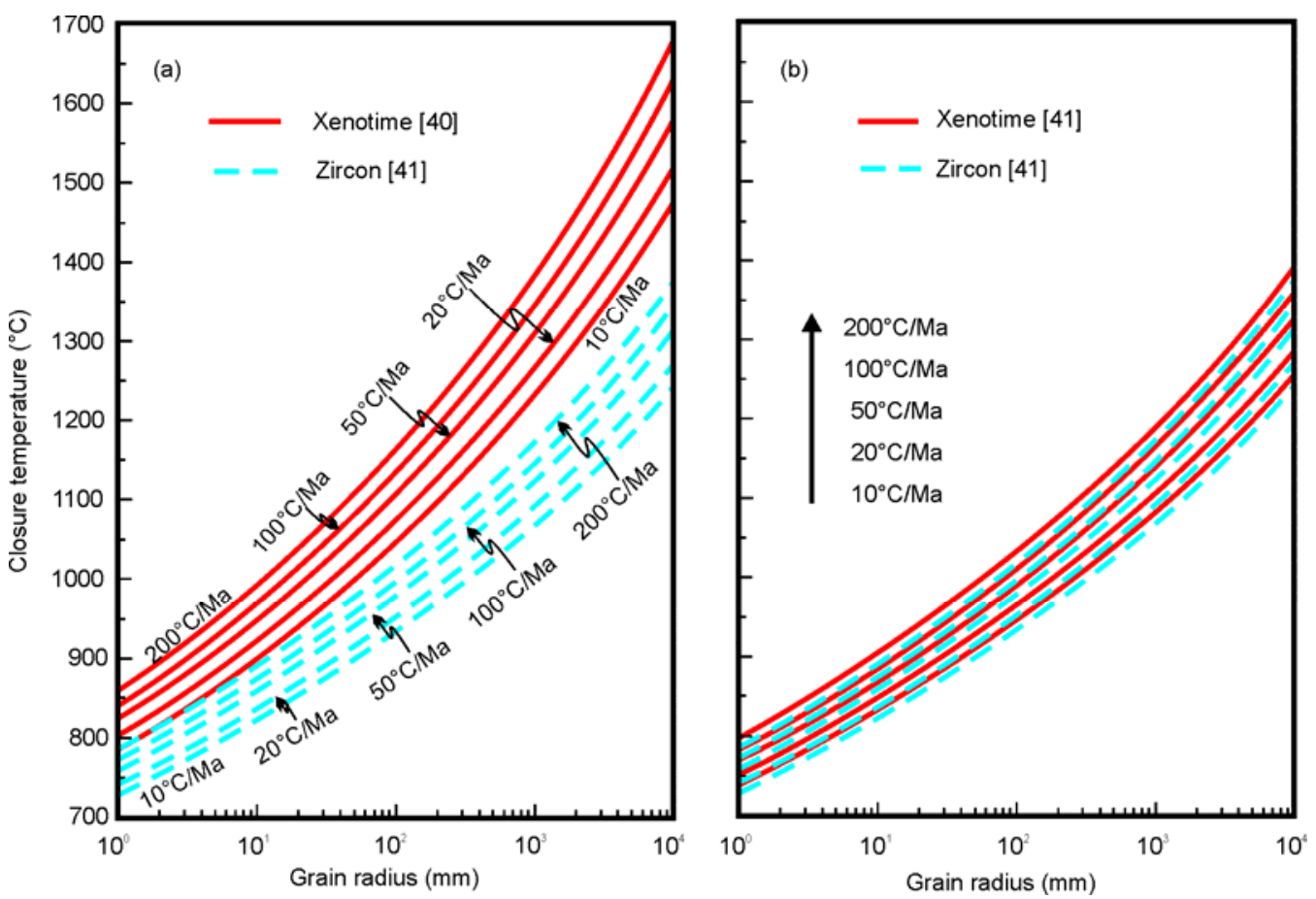

Figure 5 Closure temperatures of $\mathrm{Pb}$ diffusion in xenotime as a function of grain radius at different cooling rates, following the method of Dodson [39], and assuming mineral geometric parameter $A=55$. Diffusion coefficients for xenotime are from experimental determination of Cherniak [40] and empirical estimation of Zhao and Zheng [41]. Diffusion coefficients for zircon are empirical estimations of Zhao and Zheng [41]. 
addition, xenotime commonly coexists with monazite in rocks, and the REE partitioning between xenotime and monazite is temperature-dependent, and could be used as a potential geothermometer (such as [44]). In conclusion, xenotime could provide not only the age, but also detailed petrogenesis of the rocks.

Despite the advantages mentioned above, several difficulties exist in U-Pb dating of xenotime: (1) Xenotime is commonly small in size and rich in small inclusions, which makes it difficult to obtain enough grains for conventional ID-TIMS analyses. (2) In siliciclastic sedimentary rocks, most diagenetic xenotimes rim detrital zircon grains, and are usually $15-30 \mu \mathrm{m}$ in size. Thus, it is difficult to obtain pure mineral concentrates for conventional TIMS bulk analyses. Although in situ dating techniques provide promising results, the required high resolution presents a significant challenge. (3) Absence of acceptable standards hinders the wide application of in situ U-Pb dating. Currently, the most widely used xenotime standards include z6413, xtc, MG-1 and BS-1. z6413 is a high-U megacryst from a granite pegmatite in the Grenville Province, Ontario, Canada. The crystal is reddish-brown and measures $\sim 7 \mathrm{~mm}$ across. Stern and Rayner [49] obtained a weighted mean ${ }^{207} \mathrm{~Pb} /{ }^{206} \mathrm{~Pb}$ age of $996.6 \pm 0.8 \mathrm{Ma},{ }^{207} \mathrm{~Pb} /{ }^{235} \mathrm{U}$ age of $994.7 \pm 0.6 \mathrm{Ma}$ and ${ }^{206} \mathrm{~Pb} /{ }^{238} \mathrm{U}$ age of $993.8 \pm 0.7 \mathrm{Ma}(2 \sigma, n=5)$ by conventional ID-ITMS analyses. These ages are highly consistent, but slightly discordant. However, Schoene et al. [50] subsequently analyzed seven small fragments of z6413 by ID-TIIMS, and obtained older ages of $999.7 \pm 0.3 \mathrm{Ma}(2 \sigma)$ for ${ }^{207} \mathrm{~Pb} /{ }^{206} \mathrm{~Pb}, 998.5 \pm 0.2 \mathrm{Ma}(2 \sigma)$ for ${ }^{207} \mathrm{~Pb} /{ }^{235} \mathrm{U}$ and 997.9 $\pm 0.2 \mathrm{Ma}(2 \sigma)$ for ${ }^{206} \mathrm{~Pb} /{ }^{238} \mathrm{U}$. The inconsistent TIMS results indicate that $\mathrm{z} 6413$ may be heterogeneous in $\mathrm{U}-\mathrm{Pb}$ isotopic compositions, precluding it from being an excellent external geochronology standard. Another xenotime standard xtc with grain size up to $200 \mu \mathrm{m}$ comes from an Archaean pegmatite in the Yilgarn Craton, Australia. Some xenotime grains, however, are rich in inclusions. A previous study by the TIMS method gave $0-3 \%$ discordance ages with weighted means of ${ }^{207} \mathrm{~Pb} /{ }^{206} \mathrm{~Pb},{ }^{206} \mathrm{~Pb} /{ }^{238} \mathrm{U}$ and ${ }^{207} \mathrm{~Pb} /{ }^{235} \mathrm{U}$ ages of $2632.3 \pm 1.9 \mathrm{Ma}, 2572 \pm 33 \mathrm{Ma}$ and $2604 \pm 13 \mathrm{Ma}$ $(2 \sigma, n=4)$, respectively [6]. These results indicate that xtc has limited applicability as a U-Pb dating standard, but may be appropriate for $\mathrm{Pb}-\mathrm{Pb}$ dating. Although xenotimes MG-1 and BS-1 used in this study have homogeneous and concordant ages, their small quantities cannot satisfy the wide application for the coming in situ analyses. Hence, the development of an appropriate xenotime standard is urgently required.

\subsection{Matrix-effect}

As stated above, appropriate xenotime standards are still rare and need further research. Some studies have tried to use other materials as external standards for $\mathrm{U}-\mathrm{Pb}$ dating of xenotime. For example, Beccaletto et al. [26] used the phosphate mineral monazite as external standard, and Wall et al. [28] used a zircon standard to calibrate xenotime samples, and applied a line-scan laser ablation protocol to minimizing elemental mass fractionation. It has been also suggested that elemental mass fractionation is closely related to the analytical condition of the samples. For example, Horn et al. [51] obtained a calibration curve for the relationship between spot size and $\mathrm{Pb} / \mathrm{U}$ fractionation. No difference in this calibration curve has been observed among the glass NIST, zircon and other minerals. This led the authors to conclude that elemental mass fractionation is correlated with spot size, and that there is no need for the use of a matrix-matched material as an external standard. However, our studies here show a significant matrix-effect in U-Pb dating of xenotime by LA-ICP-MS, when different materials were used.

We obtained reliable results for BS-1 under different laser ablation conditions using MG-1 as external standard. It is reasonable to assume that the age precision increases with increasing spot size. However, using zircon or monazite as external standards, the obtained ages are inconsistent with the reference values. For example, when the monazite standard 44069 was used as standard, the obtained ages for BS-1 were older with spot size of $16 \mu \mathrm{m}$, but younger with spot sizes of 24 and $32 \mu \mathrm{m}$ compared to the reference value. This was the case even though both the monazite and xenotime samples were analyzed using the same ablation conditions. These results suggest that the calibration of elemental fractionation changes from under-correction to over-correction with increasing in spot size, and indicates a significant matrix-effect between xenotime and monazite during laser ablation. Moreover, the obtained ages may be discordant when a matrix-unmatched external standard was used. Accordingly, we conclude that the elemental fractionation is not only related to the spot size, but also to the properties of the analyzed materials. Thus, a matrixmatched material is required for U-Pb dating of xenotime by LA-ICP-MS.

\section{Conclusions}

(1) In situ U-Pb dating of xenotime by LA-ICP-MS is achievable with high levels of accuracy and precision. The obtained U-Pb ages of xenotime standard BS-1 using different spot sizes were identical to the reference age given by ID-TIMS. This suggests that the technique developed in this study is reliable. Furthermore, a young xenotime sample 09FW126( 28 Ma) was analyzed with a spot size of $24 \mu \mathrm{m}$, which yielded an accurate age consistent with previously obtained data. The precision $(1 \sigma)$ of single spot ${ }^{206} \mathrm{~Pb} /{ }^{238} \mathrm{U}$ ages ranged from $2.0 \%$ to $2.6 \%$. Thus, in situ $\mathrm{U}-\mathrm{Pb}$ dating of xenotime by LA-ICP-MS could provide accurate and precise ages, even for young samples.

(2) Necessity of a reliable matrix-matched external 
standard. Our study also suggests that accurate ages of xenotime can be obtained in various ablation conditions, if a xenotime standard is applied. However, inaccurate ages were obtained using monazite or zircon as external standards. This suggests that the matrix-effect results in significant differences in $\mathrm{Pb} / \mathrm{U}$ fractionation during laser ablation. Thus, we suggest that a matrix-matched material is required for U-Pb dating of xenotime by LA-ICP-MS.

We appreciate the supply of xenotime standards MG-1 and BS-1 by John Aleinikoff. Yang YueHeng is gratefully acknowledged for experimental assistance with this work. Constructive comments from two anonymous reviewers have substantially improved the final paper. This work was supported by the State Key Laboratory of Lithospheric Evolution (Zhuan0809).

1 Heaman L M, LeCheminant A N. Paragenesis and U-Pb systematics of baddeleyite $\left(\mathrm{ZrO}_{2}\right)$. Chem Geol, 1993, 110: 95-126

2 Chamberlain K R, Schmitt A K, Swapp S M, et al. In situ U-Pb SIMS (IN-SIMS) micro-baddeleyite daing of mafic rocks: Method with examples. Precambrian Res, 2010, 183: 379-387

3 Li Q L, Li X H, Liu Y, et al. Precise U-Pb and Th-Pb age determination of kimberlitic perovskites by secondary ion mass spectrometry. Chem Geol, 2010, 269: 396-405

4 Wu F Y, Yang Y H, Mitchell R H, et al. In situ U-Pb age determination and $\mathrm{Nd}$ isotopic analysis of perovskites from kimberlites in southern Africa and Somerset Island, Canada. Lithos, 2010, 115: 205-222

5 McNaughton N J, Rasmussen B, Fletcher I R. SHRIMP uranium-lead dating of diagenetic xenotime in siliciclastic sedimentary rocks. Science, 1999, 285: 78-80

6 Fletcher I R, Rasmussen B, McNaughton N J. SHRIMP U-Pb geochronology of authigenic xenotime and its potential for dating sedimentary basins. Aust J Earth Sci, 2000, 47: 845-859

7 England G L, Rasmussen B, McNaughton N J, et al. SHRIMP U-Pb ages of diagenetic and hydrothermal xenotime from the Archaean Witwatersrand Supergroup of South Africa. Terra Nova, 2001, 13: 360-367

8 Vallini D, Rasmussen B, Krapež B, et al. Obtaining diagenetic ages from metamorphosed sedimentary rocks: U-Pb dating of unusually coarse xenotime cement in phosphatic sandstone. Geology, 2002, 30: 1083-1086

9 Fletcher I R, McNaughton N J, Aleinikoff J, et al. Improved calibration procedures and new standards for $\mathrm{U}-\mathrm{Pb}$ and $\mathrm{Th}-\mathrm{Pb}$ dating of Phanerozoic xenotime by ion microprobe. Chem Geol, 2004, 209: 295-314

10 Kositcin N, McNaughton N J, Griffin B J, et al. Textural and geochemical discrimination between xenotime of different origin in the Archaean Witwatersrand Basin, South Africa. Geochim Cosmochim Acta, 2003, 67: 709-731

11 Rasmussen B, Fletcher I R, Bengtson S, et al. SHRIMP U-Pb dating of diagenetic xenotime in the Stirling Range Formation, Western Australia: 1.8 billion year minimum age for the Stirling biota. Precambrain Res, 2004, 133: 329-337

12 Tallarico F H B, McNaughton N J, Groves D I, et al. Geological and SHRIMP II U-Pb constraints on the age and origin of the Breves $\mathrm{Cu}-\mathrm{Au}-(\mathrm{W}-\mathrm{Bi}-\mathrm{Sn})$ deposit, Carajis, Brazil. Miner Deposita, 2004, 39: 68-86

13 Rasmussen B, Fletcher I R, Sheppard S. Isotopic dating of the migration of a low-grade metamorphic front during orogenesis. Geology, 2005, 33: 773-776

14 Mello E F, Xavier R P, McNaughton N J, et al. Age constraints on felsic intrusions, metamorphism and gold mineralisation in the Palaeoproterozoic Rio Itapicuru greenstone belt, NE Bahia State, Brazil. Miner Deposita, 2006, 40: 849-866

15 Rasmussen B, Fletcher I R, Muhling J R, et al. Prolonged history of episodic fluid flow in giant hematite ore bodies: Evidence from in situ U-Pb geochronology of hydrothermal xenotime. Earth Planet Sci Lett, 2007, 258: 249-259

16 Rasmussen B, Fletcher I R, Muhling J R. In situ U-Pb dating and element mapping of three generations of monazite: Unravelling cryptic tectonothermal events in low-grade terranes. Geochim Cosmochim Acta, 2007, 71: 670-690

17 Rasmussen B, Fletcher I R, Muhling J R, et al. Bushveld-aged fluid flow, peak metamorphism, and gold mobilization in the Witwatersrand basin, South Africa: Constraints from in situ SHRIMP U-Pb dating of monazite and xenotime. Geology, 2007, 35: 931-934

18 Sarma D S, McNaughton N J, Fletcher I R, et al. Timing of gold mineralization in the hutti gold deposit, Dharwar Craton, South India. Econ Geol, 2008, 103: 1715-1727

19 Rasmussen B, Mueller A G, Fletcher I R. Zirconolite and xenotime $\mathrm{U}-\mathrm{Pb}$ age constraints on the emplacement of the Golden Mile Dolerite sill and gold mineralization at the Mt Charlotte mine, Eastern Goldfields Province, Yilgarn Craton, Western Australia. Contrib Mineral Petr, 2009, 157: 559-572

20 Rasmussen B, Fletcher I R, Muhling J R, et al. In situ U-Th-Pb geochronology of monazite and xenotime from the Jack Hills belt: Implications for the age of deposition and metamorphism of Hadean zircons. Pbrcambrian Res, 2010, 180: 26-46

21 Suzuki K, Adachi M. Precambrian provenance and Silurian metamorphism of the tsubonosawa paragneiss in the South Kitakami Terrane, Northeast Japan, revealed by the chemical Th-U-total Pb isochron ages of monazite, zircon and xenotime. Geochem J, 1991, 25: 357-376

22 Asami M, Suzuki K, Grew E S. Chemical Th-U-total Pb dating by electron microprobe analysis of monazite, xenotime and zircon from the Archean Napier Complex, East Antarctica: Evidence for ultrahigh-temperature metamorphism at 2400 Ma. Precambrian Res, 2002, 114: 249-275

23 Salier B P, Groves D I, McNaughton N J, et al. Geochronological and stable isotope evidence for widespread orogenic gold mineralization from a deep-seated fluid source at ca. $2.65 \mathrm{Ga}$ in the Laverton gold province, Western Australia. Econ Geol, 2005, 100: 1363-1388

24 Cocherie A, Legendre O. Potential minerals for determining U-Th- $\mathrm{Pb}$ chemical age using electron microprobe. Lithos, 2007, 93: 288-309

25 Hetherington C J, Jercinovic M J, Williams M L, et al. Understanding geologic processes with xenotime: Composition, chronology, and a protocol for electron probe microanalysis. Chem Geol, 2008, 254: 133-147

26 Becccaletto L, Bonev N, Bosch D, et al. Record of a Palaeogene syn-collisional extension in the north Aegean region: Evidence from the Kemer micaschists (NW Turkey). Geol Mag, 2007, 144: 393-400

27 Klötzli E, Klötzli U, Kosler J. A possible laser ablation xenotime $\mathrm{U}-\mathrm{Pb}$ age standard: Reproducibility and accuracy. Geochim Cosmochim Acta, 2007, 71: 495

28 Wall F, Niku-Paavola V N, Storey C, et al. Xenotime-(Y) from carbonatite dykes at Lofdal, Namibia: Unusually low LREE: HREE ratio in carbonatite, and the first dating of xenotime overgrowths on zircon. Can Mineral, 2008, 46: 861-877

29 Xie L W, Zhang Y B, Zhang $\mathrm{H} \mathrm{H}$, et al. In situ simultaneous determination of trace elements, and Lu-Hf isotopes in zircon and baddeleyite. Chinese Sci Bull, 2008, 53: 1565-1573

30 Williams I S, Hergt J M. U-Pb dating of Tasmanian dolerites: A cautionary tale of SHRIMP analysis of high-U zircon. In: Woodhead J D, Hergt J M, Noble W P, eds. Beyond 2000: New Frontiers in Isotope Geoscience. Abstracts and Proceedings, Lorne, Australia. Melbourne: University of Melbourne, 2000. 185-188

31 Zhang H F, Harris N, Parrish R, et al. U-Pb ages of Kude and Sajia leucogranites in Sajia dome from North Himalaya and their geological implications. Chinese Sci Bull, 2004, 49: 2087-2092

32 Li Y D, Sheng J F, Le BEL L, et al. Evidence for the lower continental crustal source of the Xihuashan granite. Acta Geol Sin, 1986, 60: 47-64

33 Shen W Z, Xu S J, Wang Y X, et al. Study on the Nd-Sr isotope of the Xihuashan granite. Chinese Sci Bull, 39: 653-657 
34 McKee E H, Rytuba J J, Xu K Q. Geochronology of the Xihuashan composite granitic body and tungsten mineralization, Jiangxi Province, South China. Econ Geol, 1987, 82: 218-223

35 Li H Q, Liu J Q, Wei L. The Chronology of Inclusions From Hydrothermal Deposits and Its Geological Application (in Chinese). Beijing: Geological Publishing House, 1993. 956-962

36 Yang J H, Chen X Y, Wang X D. Geochronological and geochemical studies of the Dangpin granite and tungsten mineralization, Jiangxi Province (in Chinese). Acta Mineral Sin, 2009, 29(Suppl): 339-340

37 Wang R C, Fontan F, Chen X M, et al. Accessory minerals in the Xihuashan Y-enriched granitic complex, southern China: A record of magmatic and hydrothermal stages of evolution. Can Mineral, 2003, 41: 727-748

38 Crowley J L, Waters D J, Searle M P, et al. Pleistocene melting and rapid exhumation of the Nanga Parbat massif, Pakistan: Age and P-T conditions of accessory mineral growth in migmatite and leucogranite. Earth Planet Sci Lett, 2009, 288: 408-420

39 Dodson $\mathrm{M} \mathrm{H}$. Closure temperature in cooling geochronological and petrological systems. Contrib Mineral Petrol, 1973, 40: 259-274

40 Cherniak D J. Pb and rare earth element diffusion in xenotime. Lithos, 2006, 88: 1-14

41 Zhao Z F, Zheng Y F. Diffusion compensation for argon, hydrogen, lead, and strontium in minerals: Empirical relationships to crystal chemistry. Am Mineral, 2007, 92: 289-308

42 Scherer E, Münker C, Mezger K. Calibration of the lutetium-hafnium clock. Science, 2001, 293: 683-687

43 Thöni M, Miller Ch, Zanetti A, et al. Sm-Nd isotope systematics of high-REE accessory minerals and major phases: ID-TIMS, LA-ICPMS and EPMA data constrain multiple Permian-Triassic pegmatite emplacement in the Koralpe, Eastern Alps. Chem Geol, 2008, 254:
216-237

44 Andrehs G, Heinrich W. Experimental determination of REE distributions between monazite and xenotime: Potential for temperaturecalibrated geochronology. Chem Geol, 1998, 149: 83-96

45 Aleinikoff J N, Grauch R I. U-Pb geochronologic constraints on the origin of a unique monazite-xenotime gneiss, Hudson Highlands, New York. Am J Sci, 1990, 290: 522-546

46 Hawkins D P, Bowring S A. U-Pb systematics of monazite and xenotime: case studies from the Paleoproterozoic of the Grand Canyon, Arizona. Contrib Mineral Petrol, 1997, 127: 87-103

47 Schaltegger U, Pettke T, Audétat A, et al. Magmatic-to-hydrothermal crystallization in the W-Sn mineralized Mole Granite (NSW, Australia): Part I: Crystallization of zircon and REE-phosphates over three million years-A geochemical and U-Pb geochronological study. Chem Geol, 2005, 220: 215-235

48 Salier B P, Grovest D I, McNaughton N J, et al. Geochronological and stable isotope evidence for widespread orogenic gold mineralization from a deep-seated fluid Source at ca. 2.65 Ga in the Laverton Gold Province, Western Australia. Econ Geol, 2005, 100: 1363-1388

49 Stern R A, Rayner N. Ages of several xenotime megacrysts by ID-TIMS: potential reference materials for ion microprobe $\mathrm{U}-\mathrm{Pb}$ geochronology. Radiogenic Age and Isotopic Studies: Report 16, Geological Survey of Canada, Current Research 2003-F1, 2003. 1-7

50 Schoene B, Crowley J L, Condon D J, et al. Reassessing the uranium decay constants for geochronology using ID-TIMS U-Pb data. Geochim Cosmochim Acta, 2006, 70: 426-445

51 Horn I, Rudnick R L, McDonough W F. Precise elemental and isotope ratio determination by simultaneous solution nebulization and laser ablation-ICP-MS: Application to U-Pb geochronology. Chem Geol, 2000, 164: 281-301

Open Access This article is distributed under the terms of the Creative Commons Attribution License which permits any use, distribution, and reproduction in any medium, provided the original author(s) and source are credited.

\section{Supporting Information}

Xenotime is an ideal mineral for $\mathrm{U}-\mathrm{Th}-\mathrm{Pb}$ isotopic dating because of its relatively high $\mathrm{U}$ and Th contents, but typically low concentration of common $\mathrm{Pb}$. In this study, we developed a method for U-Pb dating of xenotime by LA-ICP-MS. Studies of several xenotimes gave ages in high levels of accuracy and precision, which support the reliability of the method developed here.

Appendix 1 LA-ICPMS U-Pb data and calculated ages for BS-1

Appendix 2 LA-ICPMS U-Pb data and calculated ages for xenotimes from Kudy

Appendix 3 LA-ICPMS U-Pb data and calculated ages for xenotimes from Xihuashan

The supporting information is available online at csb.scichina.com and www.springerlink.com. The supporting materials are published as submitted, without typesetting or editing. The responsibility for scientific accuracy and content remains entirely with the authors. 